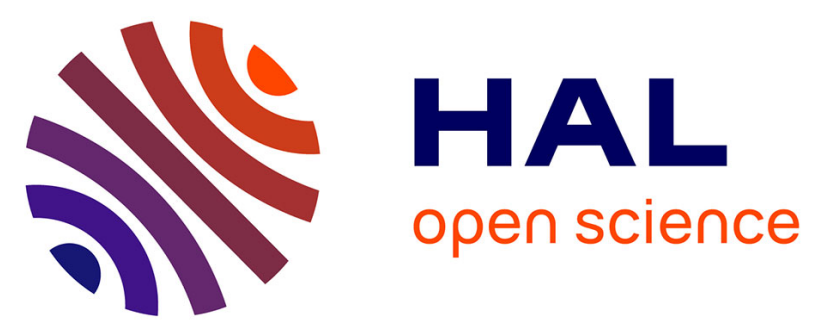

\title{
Metry Mouse Missions: An Interactive, Geometric Obstacle Course of Daredevil Proportions
}

\author{
Günter Wallner, Lauri Galbreath, Simone Kriglstein
}

\section{To cite this version:}

Günter Wallner, Lauri Galbreath, Simone Kriglstein. Metry Mouse Missions: An Interactive, Geometric Obstacle Course of Daredevil Proportions. 15th International Conference on Entertainment Computing (ICEC), Sep 2016, Wien, Austria. pp.201-204, 10.1007/978-3-319-46100-7_17. hal01640277

\section{HAL Id: hal-01640277 \\ https://hal.inria.fr/hal-01640277}

Submitted on 20 Nov 2017

HAL is a multi-disciplinary open access archive for the deposit and dissemination of scientific research documents, whether they are published or not. The documents may come from teaching and research institutions in France or abroad, or from public or private research centers.
L'archive ouverte pluridisciplinaire HAL, est destinée au dépôt et à la diffusion de documents scientifiques de niveau recherche, publiés ou non, émanant des établissements d'enseignement et de recherche français ou étrangers, des laboratoires publics ou privés. 


\title{
Metry Mouse Missions: An Interactive, Geometric Obstacle Course of Daredevil Proportions
}

\author{
Günter Wallner $^{1}$, Lauri Galbreath ${ }^{2}$, and Simone Kriglstein ${ }^{3}$ \\ 1 University of Applied Arts Vienna \\ guenter.wallner@uni-ak.ac . at \\ ${ }^{2}$ New York University \\ lauri.galbreath@nyu.edu \\ 3 Vienna University of Technology \\ simone.kriglstein@tuwien.ac.at
}

\begin{abstract}
Educational games have started to establish themselves as a fruitful complement to traditional teaching methods since they can enhance motivation and actively engage learners with the subject matter. While educational games targeted toward single players still prevail, recent years have also witnessed a growing interest to incorporate collaborative elements into educational games to take advantage of the positive effects associated with collaborative learning.

In this paper we introduce Metry Mouse Missions, an educational game which fosters collaborative problem-solving and engages young people, aged 8-11 years old, in the construction of complex geometric models through the interactive adventures of a daredevil mouse. A central aim of Metry Mouse Missions is to provide an inviting interface that supports exploration and intellectual curiosity about geometric constructions.
\end{abstract}

Keywords: Game-based learning; Collaborative learning; Geometry

\section{Introduction}

While educational games have established themselves as a promising complement to traditional education methods there still exists only a limited number of educational games to date which include a collaborative dimension (cf. [10]). While empirical studies have shown that collaborative learning can be a very effective form of learning (see, e.g., [4]), designing collaborative educational games is not a straightforward endeavor as it has been shown that the effectiveness of collaborative learning depends upon a variety of factors (cf. [1]) such as group composition and the quality of the interactions between the collaborators.

In this paper we describe Metry Mouse Missions, an educational game currently in development and intended to convey geometric concepts to young people aged 8 to 11 years. The goal of the game is to successfully maneuver a stunt mouse across obstacle courses composed of varied terrain, fire, and piranhas. For that purpose, players must unlock shapes and construct obstacle tacklers by 
correctly answering geometry-related questions about each desired game component. Metry Mouse Missions encourages students to work in pairs and promotes sustained collaborative problem solving. Friendly competition is encouraged.

\section{Related Work}

Given the vast amount of literature on game-based learning and collaborative learning environments a comprehensive review of related work is beyond the scope of this paper. We will thus limit our discussion to a few educational games concerned with teaching concepts of geometry. Examples in this area include the work of Ketamo [2] who described an adaptive geometry game for handheld devices. Sedig [8], in turn, introduced a game-based learning environment called Super Tangrams which helps children to understand transformation geometry, a topic which has also been addressed by DOGeometry [9]. Also worth mentioning is the work of Kiili and Ketamo [3] who developed a game where children learn by teaching an octopus about geometrical shapes. The latter also has a collaborative element which gives players the possibility to have their octopus compete against those trained by other players. However, each player has to train the octopus individually while in Metry Mouse Missions players have to work together to master an obstacle course.

\section{Theoretical Framework}

Metry Mouse Missions is developed with an eye towards inclusivity and constructivist learning principles. Central to a constructivist learning environment is that learners are able to choose and develop their own learning goals, and that the environment can be adapted to the uses learners put to it. The role of declarative knowledge, like facts and figures, and other forms of cognitive content, are used to help construct new worlds that reflect diverse perspectives; they are not the end in themselves, as an instructionist learning environment would have it.

Particularly useful in conceptualizing the flow of cognition in this learning game is Perkins' [7] conception of the access characteristics of knowledge, which looks at four categories of relevant knowledge (viz., knowledge, representation, retrieval, construction). Users must learn to utilize the tools of the system through physical and mental means, and construct something completely unique within it. Immediate feedback, active questioning, and interactivity increase mindfulness and intrinsic motivation [5]. Generative processing is facilitated in the game through multimedia, personalization, guided activity, feedback, and reflection [6]. The intention is to create an interactive environment that helps users develop more complicated schemata around geometry. Rewards (e.g., animations of the mouse running the obstacle course, cool things to make, racing other users) are designed into the system to keep users motivated and excited to see what comes next. 

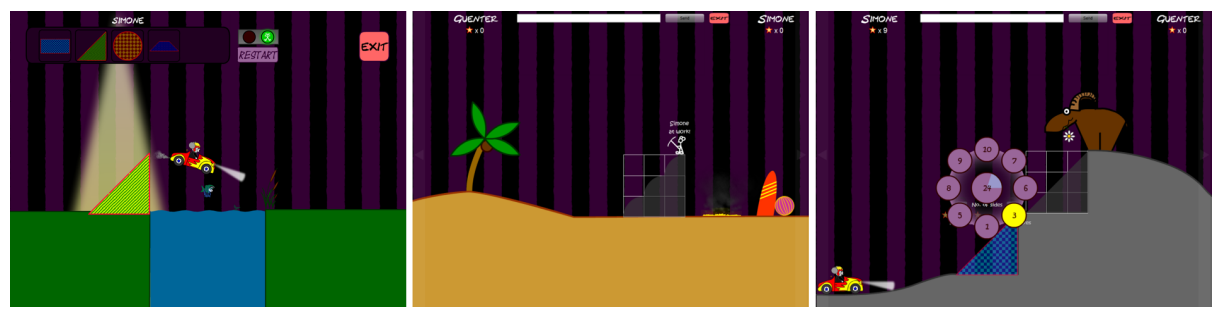

Fig. 1. Left: A tackler has been placed in front of the water hole to allow Metry Mouse to safely jump over it (single-player mode). Middle: The tackler for this fire obstacle is currently build by the other player and is therefore locked (two-player mode). Right: A player attempts to solve a question regarding the number of sides of the shape. The circle in the middle displays the amount of time left (two-player mode).

\section{Game Design}

The game consists of a collaborative two-player mode and a single player mode which is meant as a tutorial and preparation for the two-player mode. In both modes the player is challenged through a number of racetrack obstacle courses in need of various user-built contraptions (e.g., ramps, bridges) to help a stuntmouse overcome obstacles like holes, fire-pits, water holes, or hills (see Figure 1). These contraptions have to be built in an editor - called the Obstacle Tackler - by arranging basic geometric shapes - that is squares, right-sided triangles, and quadrants - in a proper way. Once the obstacle tacklers are successfully built the users may personalize their contraptions by spray painting with patterns and various color combinations. However, to place the tackler on the race track the player must unlock it first, by answering three questions about the geometric relationships involved in the construction (e.g., determining the area and circumference of a shape; recognizing the number of right angles in a shape, etc.). Each level in the game requires new tacklers to be built in order for Metry Mouse to successfully complete the race and reach the cheese located at the end of the race track.

In the single-player mode the user is aided in this process by a book, which collects all the built tacklers and gives information about the geometric relationships and equations. The two-player mode is different to the single-player mode in the sense that it limits the time available to build tacklers and answer questions. This has been done to ensure a fluent game experience for both players. Secondly, to provide incentive for both players to actively take part in the game, players can collect stars for building tacklers (the faster a tackler is built the more stars it is worth) and answering questions. In the latter case, a correct answer is worth a certain amount of stars, depending on the difficulty of the question. A wrong answer will reduce the amount by one and the players can try again, until all stars are used up in which case the level has been lost. Stars also influence the current status of the player, reaching from Boss Clown to Dare Devil. Beside the number of stars, the game keeps track of various statistics for each player 
(e.g., number of tacklers built, number of correct answers given, mostly played level) which can be viewed before challenging another player. Figure 1 shows screenshots of the game from the single-player and the two-player mode.

\section{Conclusion}

This paper provided a short overview of the game design of Metry Mouse Missions and the theoretical foundations on which its design is based. Future work will need to determine the effectiveness of the game in reaching the learning objectives by conducting user studies with young learners.

\section{References}

1. Dillenbourg, P.: Over-scripting CSCL: The risks of blending collaborative learning with instructional design. Three worlds of CSCL. Can we support CSCL? pp. 61-91 (2002)

2. Ketamo, H.: An adaptive geometry game for handheld devices. Educational Technology \& Society 6(1), 83-95 (2003)

3. Kiili, K., Ketamo, H.: Exploring the learning mechanism in educational games. Journal of Computing and Information Technology 15(4), 319-324 (2007)

4. Kyndt, E., Raes, E., Lismont, B., Timmers, F., Cascallar, E., Dochy, F.: A metaanalysis of the effects of face-to-face cooperative learning. do recent studies falsify or verify earlier findings? Educational Research Review 10, 133-149 (2013)

5. Malone, T.W., Lepper, M.R.: Making learning fun: A taxonomy of intrinsic motivations for learning. Aptitude, learning, and instruction 3(1987), 223-253 (1987)

6. Moreno, R., Mayer, R.E.: Techniques that increase generative processing in multimedia learning: Open questions for cognitive load research. In: Plass, J.L., Moreno, R., Brünken, R. (eds.) Cognitive load theory, pp. 153-177. Cambridge University Press New York, NY (2010)

7. Perkins, D.N.: Person-plus: A distributed view of thinking and learning. Distributed cognitions: Psychological and educational considerations pp. $88-110$ (1993)

8. Sedig, K.: From play to thoughtful learning: A design strategy to engage children with mathematical representations. Journal of Computers in Mathematics and Science Teaching 27(1), 65-101 (2008)

9. Wallner, G., Kriglstein, S.: Design and evaluation of the educational game DOGeometry: A case study. In: Proc. of the 8th International Conference on Advances in Computer Entertainment Technology. pp. 14:1-14:8. ACE '11, ACM (2011)

10. Wendel, V., Gutjahr, M., Göbel, S., Steinmetz, R.: Designing collaborative multiplayer serious games. Education and Information Technologies 18(2), 287-308 (2013) 